Article

\title{
A Study on the Formation Environment of the La Cumbre Amber Deposit, from Santiago Province, the Northwestern Part of the Dominican Republic
}

\author{
Paweł Stach ${ }^{1, *} \mathbb{D}$, Lucyna Natkaniec-Nowak ${ }^{1}$, Marian Wagner ${ }^{1}$, \\ Magdalena Dumańska-Słowik ${ }^{1}$ (D), Maja Mroczkowska-Szerszeń ${ }^{2}$ (D), \\ Aleksandra Wesełucha-Birczyńska ${ }^{3}$, Przemysław Drzewicz ${ }^{4} \mathbb{D}$, Carlos George ${ }^{5}$ \\ and Edwin Garcia ${ }^{6}$ \\ 1 Faculty of Geology, Geophysics and Environmental Protection, AGH University of Science and Technology, \\ 30 Mickiewicza Av., 30-059 Krakow, Poland; natkan@agh.edu.pl (L.N.-N.); \\ m.wagner43@upcpoczta.pl (M.W.); dumanska@agh.edu.pl (M.D.-S.) \\ 2 Oil and Gas Institute-National Research Institute, 25 Lubicz Str., 31-503 Krakow, Poland; \\ mroczkowska@inig.pl \\ 3 Faculty of Chemistry, Jagiellonian University, 2 Gronostajowa Str., 30-387 Krakow, Poland; \\ aleksandra.weselucha-birczynska@uj.edu.pl \\ 4 The Polish Geological Institute-National Research Institute, 4 Rakowiecka Str., 00-975 Warsaw, Poland; \\ przemyslaw.drzewicz@pgi.gov.pl \\ 5 Dirección General de Minería, L. Navarro Av., Santo Domingo 10201, Dominican Republic; \\ carlos.george@dgm.gov.do \\ 6 Faculty of Engineering and Natural Resources, UTECO La Universidad Tecnologica del Cibao Oriental, \\ Ave Universitaria No. 100, Cotuí 43000, Dominican Republic; coralaltagracia@hotmail.com \\ * Correspondence: pstach@agh.edu.pl
}

Received: 18 July 2020; Accepted: 12 August 2020; Published: 21 August 2020

check for updates

\begin{abstract}
The amber-bearing coaly shale from the La Cumbre deposit (Cordillera Septentrional, Dominican Republic) contains a large quantity of altered, coalified plant detritus. The coals in these shales are in the transition stage from meta-lignite to subbituminous coals. They are composed mainly of inertinite macerals such as fusinite, semifusinite, macrinite and secretinite. Fossil resin found in the deposit occurs in two forms: detrital grains up to several centimetres in size (type I) and very fine authigenic grains, of a few micrometers in size, inside the humic laminae (type II, resinite). The detrital fossil resins are transparent, with few mineral and organic inclusions. In their composition they contain sulfides, which may come from sulfate reduction, inclusions of plants and/or insects or be caused by volcanic activity developed in surrounding coal series. The resinites are strongly saturated with various inclusions and spatially associated with framboidal pyrite aggregates. Both fossil resin types were probably deposited in a shallow coastal lake environment in the zone bordering the floodplain of the river, with periodic floods. The marine environment conditions, which were progressively changing from oxidizing to reducing, are likely associated with the formation of the fossil resin.
\end{abstract}

Keywords: Dominican amber; La Cumbre deposit; Raman spectroscopy; facies analyses; petrology; coaly shale

\section{Introduction}

Naturally occurring fossil resins are caustobioliths, organic sediments of plant origin [1]. They are products of the vital processes in various species of angiosperm and gymnosperm taxa and play a crucial 
role in self-defence mechanisms against insect herbivores, and in healing wounds to prevent bacterial and fungal infections [2]. Under the influence of atmospheric conditions and sunlight, residual volatile essential oils escape from the resins. Over time, the resins harden, due to the gradual polymerization of their chemical compounds [3]. Their further changes are the result of environmental factors, including climate and biosphere activities, and also of geological processes such as volcanism and postmagmatic hydrothermal activity [2,4]. These factors have a significant influence on the chemical composition of resin. Using carefully selected analytical techniques, the original nature of the material and its evolutionary alterations can be reconstructed. It is well known that all the changes resin undergoes are recorded in its chemical structure, regardless of the botanical source (resinous species) [2,3,5-10].

In terms of chemical composition, resins are lipid-soluble mixtures of volatile and non-volatile terpenoid or phenolic compounds that are produced by plants [2,5]. Based on their age, resins can be divided into groups: modern ( $<250$ years old), ancient (250-5000 years old), subfossil (5000-40,000 years old) and fossil (>40,000 years old) [2,11-18]. The age assessment of fossil resins older than 40,000 years is based on the stratigraphic dating of the host rocks, because 40,000 years is the limit for $\mathrm{C}^{14}$ carbon dating [19]. However, it is very difficult to determine the age of fossil resins which have undergone redeposition [6]. The worldwide fossil resin deposits are associated with sediments of different ages from Carboniferous to late Pleistocene. Today, almost all fossil resins are called "amber"(excluding resinite), e.g., Baltic amber, Indonesian amber and Dominican amber. They are valued for their properties and considered as organic gemstones and hence frequently used in jewelry. Another term used by coal geologists for amber and fossil resins is resinite, which is a microscopic material often found in coal macerals [2,5,20,21].

The amber deposits in the Dominican Republic occur in two main regions, i.e., the Cordillera Septentrional, north of Santiago de los Caballeros (Northern Mining District-NMD) and the Cordillera Oriental, northeast of Santo Domingo (Eastern Mining District-EMD) (Figure 1). Recent palaeogeographic studies suggest that both northern and eastern amber deposits were part of the same sedimentary basin, which was separated in the past due to movements along the faults [13]. The fossil resins originate mainly from the Hymenaea protera (Fabaceae) tree species and they are dated from the Oligocene to Miocene, i.e., about 25-20 Ma [13,22,23]. The oldest and hardest Dominican amber comes from the Cordillera Septentrional region (NMD) [10,13,20,24-26]. It is found in the mining sites, such as La Cumbre, La Toca, Palo Quemado, La Bucara, Los Higos, Pecado Bobo, Juan de Nina and Los Cacaos (Figure 1). In the Cordillera Oriental (EMD), fossil resins are found in San Rafael, El Cabao, Yanigua and Siete Cañadas. Fossil resins have also been found in Comatillo and Sierra de Agua, in the Bayaguana region (Figure 1).

In the NMD region of the Cordillera Septentrional, amber is manually extracted using pickaxes and drills from relatively shallow and narrow shafts. Amber mining, jewelry manufacturing and its marketing have great economic importance in the region, especially in La Cumbre. Dominican amber exists in many colors, but yellow and yellow-brown varieties are the most common. Red, green and blue fluorescent amber are less abundant. The latter occurs mostly in the Palo Quemado mine, south of La Cumbre. 


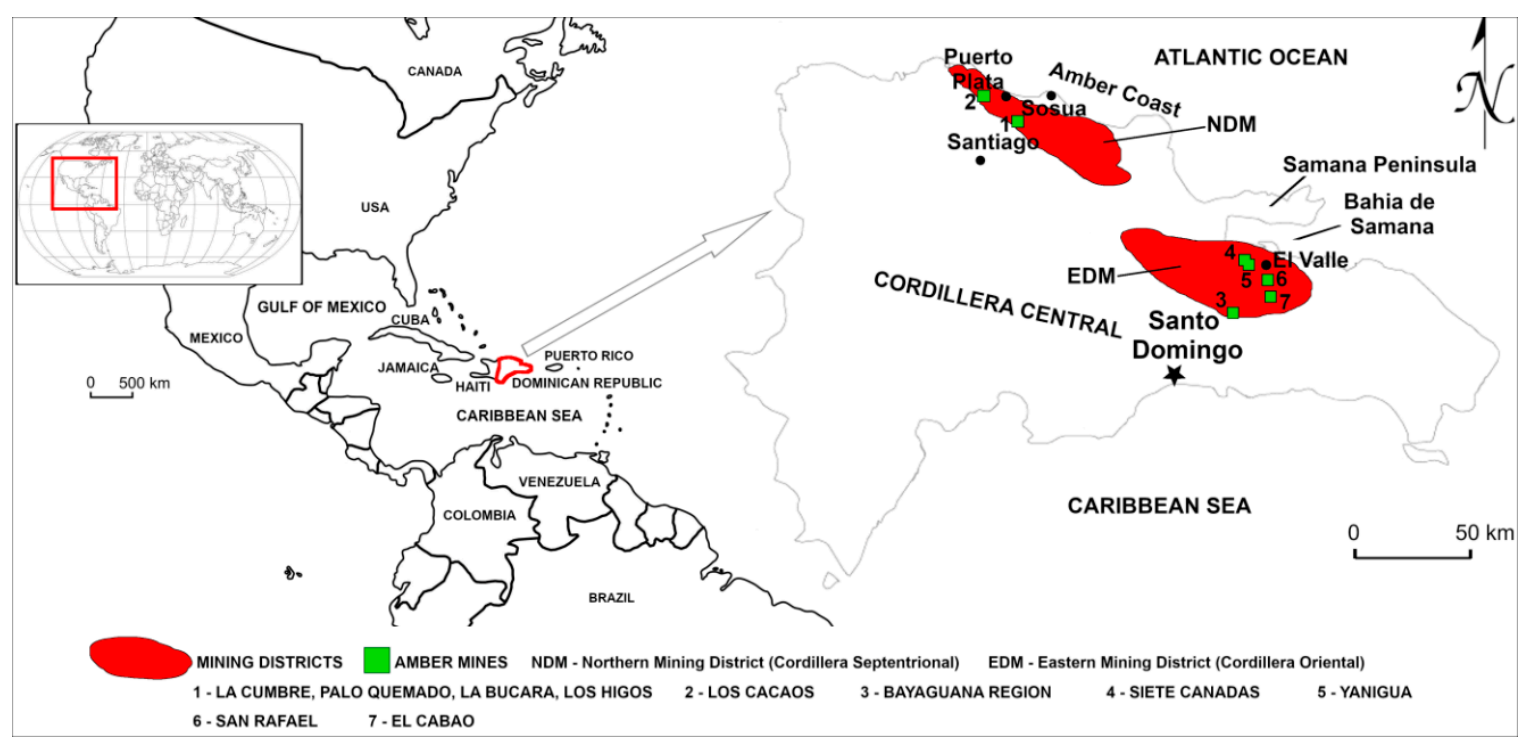

Figure 1. Sketch map of the Dominican Republic with the location of the amber deposits in Santiago Province and Hato Mayor Province.

In this paper, samples of amber-bearing coaly shales from the La Cumbre mine were studied in detail to reveal their petrogenesis. The rocks, containing fragments of coalified wood, were found in the La Toca Formation lignite beds $[13,27,28]$. The lower part of the unit was probably formed in terrestrial conditions (a shallow lake) near the seashore; however, the deposition of amber-bearing sediments probably took place in a shallow sea environment [13]. To confirm or exclude this hypothesis, comprehensive mineralogical and petrological analyses of the rock samples from La Cumbre mine were completed. The abundant coalified plant detritus found in the rocks is described together with fossil resins accompanying its accumulations. The quantification of macerals and minerals in the rocks was determined by facies analysis proposed by Kalkreuth et al. [29] for Miocene sediments from Greece (Meliadi Mine) and Gruber and Sachsenhofer [30] for Miocene sediments from the Noric Depression (Eastern Alps). These procedures [29,30] were modified after the classical models of Diessel [31] and Calder et al. [32].

The models of Diessel [31] and Calder et al. [32], which are best documented in the sedimentological literature, were adopted for this study. They concern Palaeozoic moors (of the Permian period). However, the wetlands in the history of Earth have all been subjected to the same or similar geological and ecological conditions. The tissue content of marsh plants, the plant products and mineral substances were identical in the Mesozoic and Cenozoic eras to those of the Permian period (Paleozoic era). Hence, the development of coal macerals has hardly changed in these different eras (principle of uniformitarianism), with the same conditions in the "coaly metamorphism" [33]. In the scientific literature, this point of view has been used repeatedly for Carboniferous, Cretaceous [34-37] and younger coaly deposits, i.e., Tertiary [30,38-40]. As an example, the work of Kalkreuth et al. [29] was used as reference material in this study. In some rare cases, like for non-redeposited resinite, especially in low-rank coal, thermal history investigation may be supported by microfossil analysis, Fourier transform infrared spectroscopy (FTIR) and Raman analysis. An effort has been made to determine the rate of maturity of fossil resin deposited in the mudrocks (this is frequently done, for example, in the case of Dominican fossil resins) by referencing it against the rate of maturity of organic matter in the rock matrix containing the amber. The resin matrix itself may also be analyzed with FTIR and Raman methods since they are both tools used to investigate fossil resins according to their origin $[6,41]$. Besides the reconstruction of the palaeoenvironment of amber deposition in the La Cumbre mine, this study characterized the two distinct types of fossil resin (I and II) in these rocks, based on microhardness measurements, microscopic observations and Raman spectroscopy (RS), to elucidate their origins and reconstruct their evolutionary history. 
Type II fossil resins, due to their microscopic size and the presence inside humic laminae, correspond to the definition of resinite. In turn, larger fragments of detrital resin (type I) are referred to in this paper as fossil resins or amber.

\section{Materials and Methods}

\subsection{Sampling}

The lithological description and collection of five samples from the La Cumbre amber deposit were carried out by the co-author of this paper (Carlos George). The rock samples were taken from an inclined well, from the resin-bearing horizon, at a depth of 10 meters below the ground surface. The samples were analyzed with stereoscopic and polarizing microscopes under transmitted, reflected and ultraviolet (UV) light. All petrographic examinations and their sedimentological interpretations were performed at the Laboratory of Coal Mining Geology in the Department of Geology of Mineral Deposits and Mining Geology of the Faculty of Geology, Geophysics and Environmental Protection, AGH University of Science and Technology, Krakow, Poland. The microhardness testing of amber was carried out at the Gemological Laboratory in the Department of Mineralogy, Petrography and Geochemistry of the same university and faculty. The Raman spectra of fossil resins were recorded at the Laboratory of Raman Spectroscopy of the Faculty of Chemistry, Jagiellonian University in Krakow, Poland and the Oil and Gas Institute, National Research Institute in Krakow, Poland.

\subsection{Analytical Methods}

The preliminary observations of the textural characteristics of the rocks and their composition were made using a stereoscopic microscope Motic SNZ-168 (Xiamen, China), coupled with a digital camera (with $0.75 \times, 1 \times, 2 \times, 3 \times, 4 \times$ and $5 \times$ objectives), supported by Huvitz Panasis software. The intensity of the fluorescence phenomenon was recorded using a Schneider UV lamp (Idar Oberstein, Germany) with 365-nm longwave (UVL) and 254-nm shortwave (UVS) ultraviolet light drawer-type darkroom observation.

The standard optical observations under transmitted light were carried out with Olympus BX 51 (Tokyo, Japan) and Motic BA310POL (Xiamen, China) polarization microscopes coupled with a digital camera and Huvitz Panasis software for the photographic documentation. The petrographic investigations of the polished sections (transverse sections) under transmitted and reflected light were performed with a binocular magnifier PZO (Polskie Zakłady Optyczne, Warsaw, Poland) and polarized light microscope, Axioplan (Zeiss-Opton, Oberkochen, Germany). The measurements of the random reflectance $\left(\mathrm{R}_{\mathrm{r}}{ }^{\circ}\right)$ of coal were done with an Axioplan MPM-400 photometer under standard conditions [42]. The fossil resin pieces were observed under blue fluorescent reflected light using Schött filters. The investigations of the ore minerals were carried out using a Nicon Eclipse C/POL (Tokyo, Japan) polarized light microscope equipped with a Olympus DP-12 microscope camera (Tokyo, Japan).

The facies analysis was performed according to Kalkreuth et al. [29] and Gruber and Sachsenhofer [30]. Analyses were modeled and modified according to procedures reported by Diessel [31] and Calder et al. [32] and the current petrographic standards of the International Committee for Coal and Organic Petrology (ICCP) and 7404-3:2009 standards [43] to determine the origin of the sediments from the La Cumbre deposit. The tests were carried out both on thin sections and polished surfaces of the rocks under transmitted, reflected and fluorescent blue light. The quantitative petrographic analysis was performed by converting 500 intersection points. Facies indicators proposed by Kalkreuth et al. [29] and Gruber and Sachsenhofer [30] were determined during the petrographic analysis of coaly shale (Table 1). 
Table 1. Formulae and meaning of sedimentological indicators used to describe the sedimentological description of coaly shale.

\begin{tabular}{cc}
\hline Index & Index Significance \\
\hline Gelification index $(\mathbf{G I})$ & macerals gelified to inert tissues \\
Vegetation index $(\mathbf{V I})$ & $\begin{array}{c}\text { and cutinite } \\
\text { tissue macerals with sporite, alginite }\end{array}$ \\
$\begin{array}{c}\text { Goundwater horizon location index }(\mathbf{G W I}) \\
\text { Preserved plant tissue index (TPI) }\end{array}$ & $\begin{array}{c}\text { gelified macerals and minerals to the huminite group macerals } \\
\text { tissue macerals (from the group of huminite and inertinite) to } \\
\text { detrital with gelinite }\end{array}$ \\
\hline
\end{tabular}

Microhardness parameters of amber were determined using a microhardness tester PMT-3 (LOMO, Leningrad, Russia). Microhardness measurements were collected using the Vickers method in accordance with the ISO 6507-1:2018 standard [44]. The surface of the amber sample (approximately $25 \mathrm{~g}$ ) was polished to obtain a flat plane for undistorted observation of the diamond pyramid mark. The samples were subjected to pressure induced by a diamond pyramid tip for $15 \mathrm{~s}$. The microhardness test was repeated 20 times, each time at a different point on the surface of the sample. The measurements were only performed on pieces of the detrital fossil resin (type I). The type II resinite were too small for such tests. The measurement results are given in " $\mathrm{kgf} / \mathrm{mm}^{2}$ ", which means "kilogram force per square millimeter"; according to International System of Units (SI), $1 \mathrm{kgf} / \mathrm{mm}^{2}=9.806 \times 106 \mathrm{~N} / \mathrm{m}^{2}=9.806 \mathrm{MN} / \mathrm{m}^{2}=9.806 \mathrm{MPa} ; 1 \mathrm{~N} / \mathrm{m}^{2}=1 \mathrm{~Pa}$. For convenience, they are also given in MPa.

The Raman spectra of detrital fossil resin (type I) were obtained using a Thermo Scientific Nicolet NXR 9650 FT-Raman spectrometer (Thermo Electron Scientific Instruments LLC, Madison, WI, USA) equipped with a micro-stage microscope. The samples were excited with a 1064-nm line of the Nd:YAG laser (supplied by Thermo Scientific Inc., Waltham, MA, USA), applying a power of $200 \mathrm{~mW}$ in the range $4000-400 \mathrm{~cm}^{-1}$ for each sample. The resolution was set to $4 \mathrm{~cm}^{-1}$.

A Renishaw inVia spectrometer (Wotton-under-Edge, Gloucestershire, UK) connected to a Leica microscope (Wetzlar, Germany) was used to measure the Raman spectra of tiny authigenic resinite grains (type II). A beam from a 514.5-nm argon ion (Modu-Laser, UT, USA) laser was focused on the samples with the Leica $100 \times$ magnification objective with a high numerical aperture (NA equal to 0.9). Raman light was dispersed by a diffraction grating of $2400 \mathrm{~L} / \mathrm{mm}$. Laser power directed at the sample was kept very low, ca. $0.5-1 \mathrm{~mW}$, as specimens were very sensitive to laser light.

It was impossible to collect Raman spectra from both fossil resin types using 1064-nm laser line excitation. The application of a near-infrared range wavelength for tiny resinite grains (type II) resulted in the generation of a high background that, even at very low laser power, exceeded the detection capabilities. However, the spectra of larger fossil resin pieces (type I) could not be measured with laser light at the 514.5-nm wavelength due to the fluorescence of the samples.

\section{Geological Setting}

In the NMD, the graben La Toca Block, which is a part of the El Mamey Belt, is made of deformed Mesozoic and Cenozoic rocks (Figure 2). The Oligocene and Miocene sediments comprise two series of rocks, i.e., the La Toca (Upper Oligocene-Middle Miocene) and Villa Trina Formations (Middle/Upper Miocene-Pliocene). The resin-bearing sediments, both para- and ortho-conglomerates, occur in the upper part of the La Toca Formation [27,45,46]. Near the outcrops of the Pedro Garcia Formation (Upper Cretaceous), the clasts of these sediments include: 70\% volcanic rocks (tuffs, andesites and basaltic lavas), $20 \%$ intrusive rocks (tonalites) and 10\% sandstones, shales, recrystallized limestone, serpentinites and others. This indicates that the clastic material probably came from the elevated rocks of the Pedro Garcia Formation $[13,27,45,46]$. The composition and sedimentation features of the lower conglomerate suggest that the clastic materials originated from a local source and were formed under the influence of debris flow in a terrestrial environment, but near the seashore. Presumably, the material might be associated with the uplift of a mountain range [13]. 


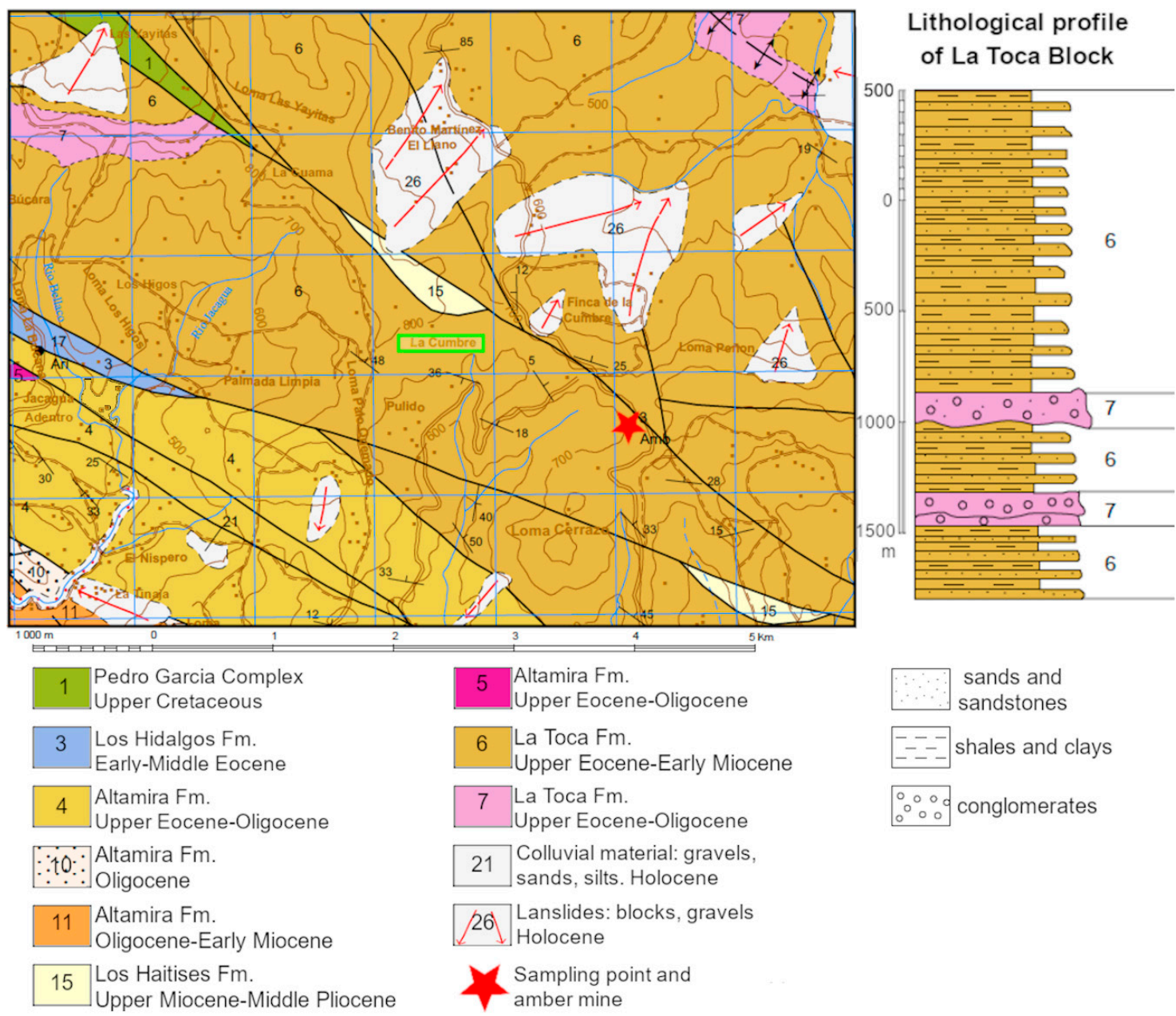

Figure 2. Geological map with the location of the sampling site in La Cumbre mine, based on the Geological Map of the Dominican Republic at 1:50 000 scale (San Francisco Above (sheet 6074-I)) [47]. Legend: 1-Volcanoclastic, pyroclastic and subvolcanic rocks, 3-Recrystallized limestones, 4-Alternation of sandstones and clays, local conglomerates, 5-Breccias and conglomerates with andesites and limestones, 6-Rhythmic alternations of sandstones and clays, 7-Conglomerates, 10-Polymictic conglomerates, 11-Rhythmic alternations of sandstones and clays, 15-Micritic limestones and reef limestones.

La Cumbre is a mining site in the Cordillera Septentrional (Figure 1), where fossil resins are manually excavated from approximately $60-\mathrm{m}$ deep shafts. Iturralde-Vinent [13] estimated the age of amber-bearing sediments of this region to be Early-Middle Miocene. The fossil resins are hosted in the sandstone layers with fragments of lignite or within lignite seams [48]. They are most often found in laminated, blue-gray, fine-grained sandstones and mudstones rich in biotite and organic matter (flysch type) and rarely within coaly shales. The fossil resins occur in three to five levels of the profiles in the deposit. Thus, it may be suggested that fossil resins were deposited in the marine environment near the river delta [13] in a relatively short time [49].

\section{Results}

\subsection{Macroscopic Characterization}

The rock samples exhibit a typical parallel, stratified texture. They are composed of coal mudstone layers (from 1.0 to $1.5 \mathrm{~cm}$ thick) alternating with lignite lamina (from a fraction of a $\mathrm{mm}$ to about $3.0 \mathrm{~mm}$ thick). Locally, very fine (approximately 2.0 - to $3.0-\mathrm{mm}$ wide) lenses of pure claystone are visible between these layers. 
The rocks contain a wealth of fossil resin pieces of various sizes, for which the diameter ranges from hardly noticeable (approximately $0.1 \mathrm{~mm}$ ) up to $50 \times 17 \mathrm{~mm}$ (Figure 3A,B). Two types of fossil resin were distinguished, differing in size, shape and place of accumulation in the host rocks. The larger, irregularly shaped fossil resin pieces (type I) are irregularly scattered within the clay mudstone matrix, whereas the smaller oval-shaped resinites (type II) of are only hosted within coal layers. Both fossil resins are transparent with a yellow to yellow-brown color and waxy luster. They are brittle far more than the accompanying coal) and visibly cracked. They crumble easily under the influence of even weak mechanical pressure. Their fracture surfaces are uneven and, in some cases, conchoidal, resembling glass. Both smaller (type II) and larger (type I) grains of fossil resin do not show any luminescence under white light (Figure 3A). Under UV light, they exhibit a similar intensity of blue fluorescence (Figure 3B-D). Under UVS excitation $(254 \mathrm{~nm})$, their fluorescence is weak to moderate and, under UVL excitation (365 nm), very strong.

Distinctive, strongly macerated, charred and coalified phytogenic detritus was observed on the planes of the rock layers (Figure 3B). The coal layers are made of lignite, which forms elongated thin lamina and lenses up to $3.0 \mathrm{~mm}$ thick (usually from 0.5 to $1.5 \mathrm{~mm}$ in size). The coal is black with a brown tint and brown streak. It is homogenized due to strong gelification. It has a matte to semivitreous luster, an uneven granular or sometimes conchoidal fracture and distinct cubic divisibility (endogenous cleavage). The morphology of the coal indicates that it consists of coalified wood fragments (strongly gelled xylites) and relatively large but poorly preserved macerated leaves, as well as plant detritus found locally in layers enriched with clay and sandy components.

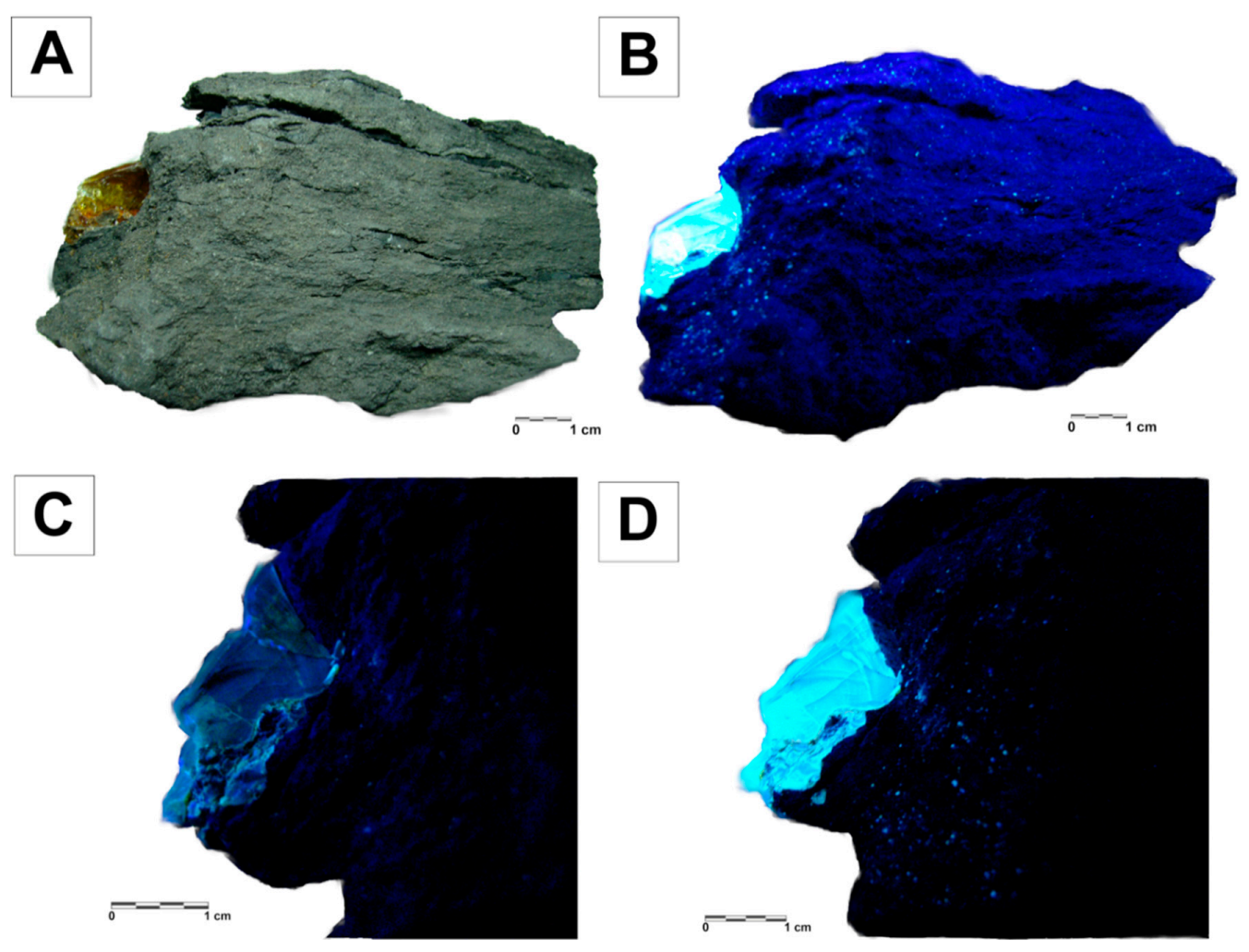

Figure 3. (A) Sample of coaly shale with large and tiny fossil resin pieces and a fine stratified texture; (B) The rock under UVL light (365 nm); Various colors and intensities of fossil resin fluorescence under UVS light $=254 \mathrm{~nm}(\mathbf{C})$ and under UVL light $=365 \mathrm{~nm}(\mathbf{D})$.

Macroscopically, coal does not meet the requirements for coal lithotypes in terms of thickness. Existing only in coaly shales, it is dark brown to black, semibright, gelified and stratified xylite-rich coal (ICCP). According to the latest proposal of the universal ICCP classification, it is the petrological equivalent of stratified, xylitic (gelified) coal [50]. In the border zone of meta-phase varieties, there is 
a divergence with typical differences at a macroscopic scale and in the chemical structure [51]. On the surface of a few xylitic species, gelified fragments of coniferous tree cork (bark) have been preserved.

\subsection{Microscopic Observations Under Transmitted and Reflected Light}

The presence of horizontal lamination of the rocks and the clay-carbon and lignite lamina (maximum $3.0 \mathrm{~mm}$ thick) are visible under the microscope (Figure 4A). Locally, the texture of these rocks is disturbed by density bumps formed by the sinking of larger detrital grains into an unconsolidated clay mud mass during sedimentation. This is manifested by the interruption of continuity in some layers and the disturbance of coaly lamina (Figure 4B). The length of density bumps is up to several millimeters in the direction perpendicular to the layer.

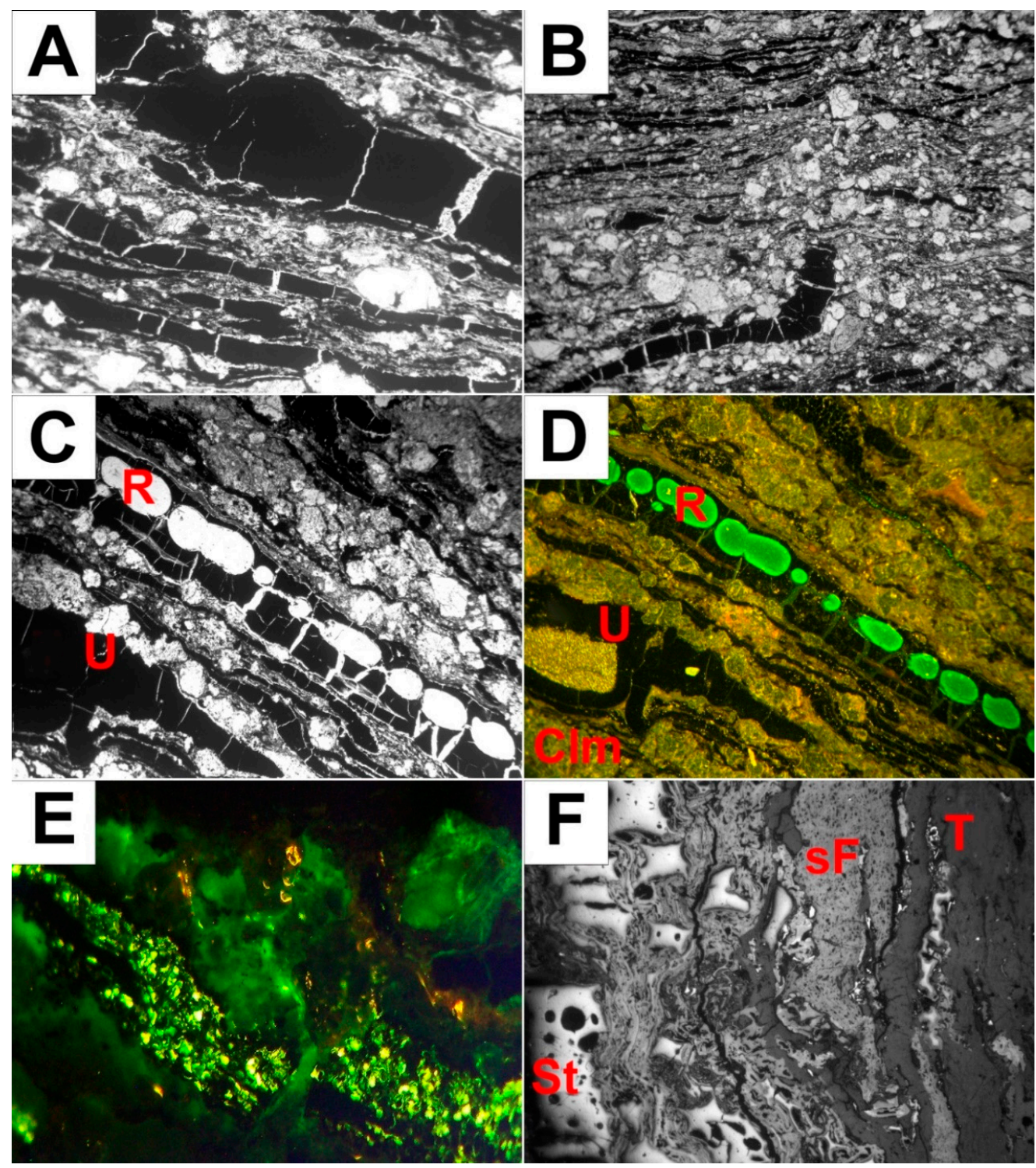

Figure 4. Microphotographs of coaly shale. The linear nature of the rock under polarized transmitted light: (A) Magnification 125x; (B) 75x; clusters of resinite (R) in ulminite (U) films and clay minerals (Clm): (C) Transmitted white light, 75×; (D) Reflected light, blue fluorescent, 75×; (E) Clusters of fluorinite and liptodetrinite in coal (reflected light, blue fluorescent, 500x; (F) Secretinite (St), semifusinite $(\mathrm{sF})$ and textinite $(\mathrm{T})$ inclusions in coal (polarized reflected light, 500×).

The rock matrix is mainly built of a mixture of very fine-grained clay minerals and detritic material. The largest aggregates have been identified as kaolinite, which crystallized as elongated, columnar 
crystals, sometimes in worm-like forms. The smaller aggregates of clay minerals form clusters of hydromicas (illite). They are usually yellow-brown, probably due to the strongly dispersed coal dust on their planes. In most layers, except for pure clay laminas, there are numerous detrital quartz grains (approximately 45\% vol.), kaolinite-forming pseudomorphs after feldspars, amphibole group minerals, mica flakes, carbonate, and gypsum crystals, as well as zircon and titanium oxides. In general, the detrital material is quite well rounded and poorly sorted.

Quartz predominates over the other detrital components of the rocks. It has different shapes, with a maximum size of $1.5 \mathrm{~mm}$. Most grains are more or less rounded and only the smallest have sharp edges. Together with feldspars, quartz forms small lenticular clusters (up to $5.0 \mathrm{~mm}$ long). Quartz exhibits uniform extinction of light. There are also forms typical of pyrogenic quartz in the rock matrix. Plagioclases, with visible albite twinning, appear to be the most abundant among the feldspars. However, the advanced degree of their weathering and the formation of clay minerals, as a result, caused turbidity of the feldspar planes. Hence, the identification of feldspars was ambiguous. Gypsum-forming characteristic rosette clusters and rhomboidal calcite crystals occur as accessory components of the rocks. Additionally, abundant grains and clusters of framboidal pyrite are found within the clay-coal layers.

\subsection{Quantitative Composition of the Coaly Shales}

The coal layers in these rocks are mainly composed of ulminite and textinite with poorly preserved cellular structure (Figure 5A). However, some layers built of ulminite are two phase. In the almost homogeneous background of eu-ulminite, with an average reflectance coefficient of 0.37 to $0.40 \%$ (average $0.39 \%$ ), there are noticeable bands with a slightly higher reflectance coefficient $(0.40-0.44 \%)$, with fuzzy crevices, diagnostic for pseudo-huminite with a slitted structure, which is a precursor of pseudo-vitrinite [52]. The origin of pseudo-huminite could be associated with the spongy tissue of higher plants (vascular plants), e.g., thick tropical leaves [52]. Such fragments of plants, which were less gelified and thus not compressed, have been preserved in the form of phyllo-telinite (Figure 5B). They indicate the presence of leaf residues of subtropical or tropical plants in the rocks, with a large content of the palisade tissue or parenchyma in the structure of the leaf. All gelified clusters are characteristically cracked with an exogenous cleavage (desiccation cracks), which indicates a strong gelification process in the basin under reducing conditions and then dehumidification, e.g., due to the lowering of the water level. The gelification of organic material under reducing conditions is also confirmed by the numerous bacterial-originated pyrites present in these layers. The cleavage cracks are sometimes empty, partially filled or filled with clay minerals and detrital material.

In the petrographic composition of the coal, there are also a few plant spores (Figure 5C) and tiny animal remains (Figure 5D) loosely distributed in the clay background (not trapped in the fossil resins). Clusters of fluorinite are other diagnostic coal microcomponents (Figure 4E). These are the petrified droplets of the essential oils of plants classified as balsamic herbs that occur in the humid areas of the floodplains of rivers, mostly in the border area with permanent lakes [53].

One of the best ways to assess the degree of coalification of altered phytogenic material is the measurement of the random reflectance of eu-ulminite B. Due to their genetic origin, ulminite layers in the shales enable precise assessment of their degree of coalification. Important statistical parameters for the distribution of the random reflectivity of coal are presented in Table 2. They indicate the normal distribution of the reflectogram (Gaussian curve). The average random reflectance of eu-ulminite B from several coal samples is $0.39 \%$ with a standard deviation (stdv) of $0.03 \%$. The petrographic composition of the coaly shales is presented in Table 3. 


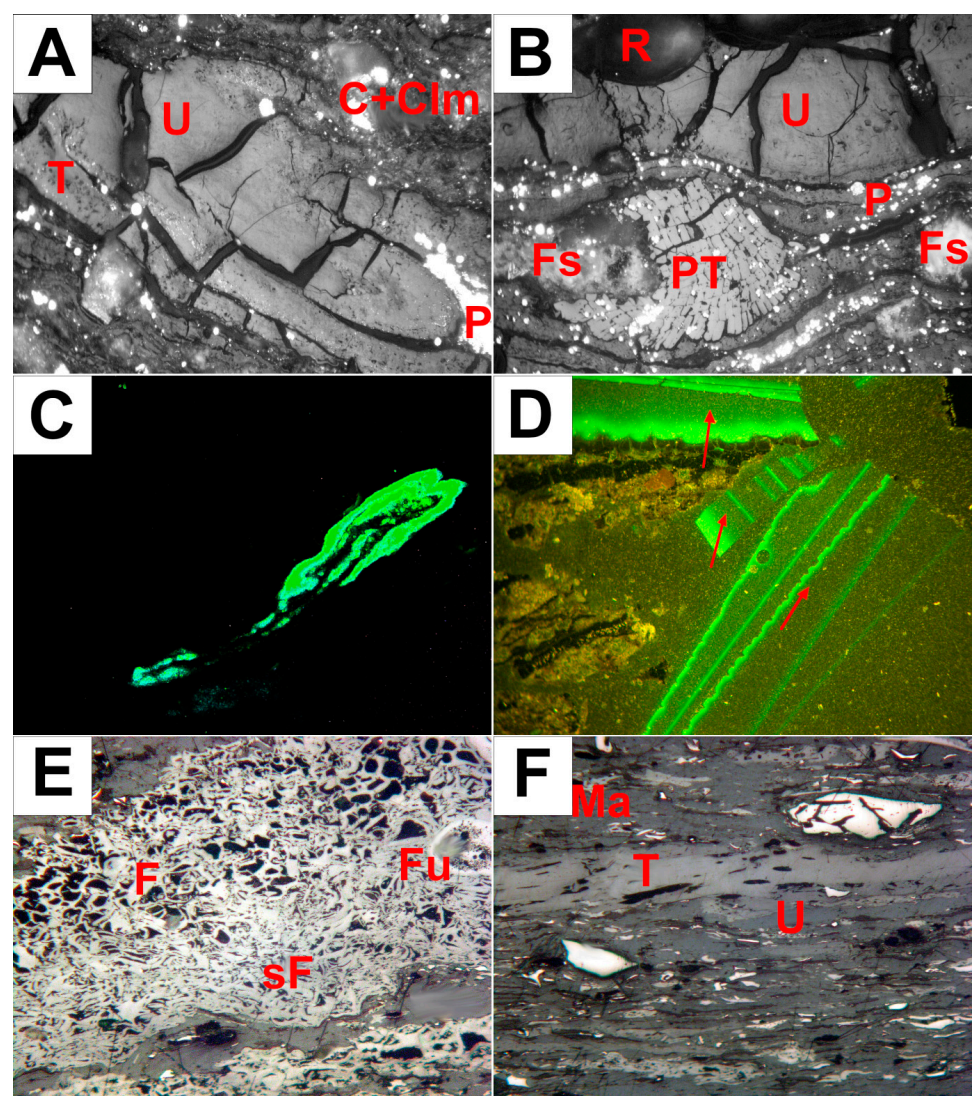

Figure 5. Petrographic nature and composition of coal in the rock. (A) Petrographic composition of coaly laminae (polarized reflected light, magnification 200x; T—textinite, EU—eu-ulminite, C+Clm—clay minerals and weathered feldspar, $\mathrm{P}$-pyrite); (B) Texto-ulminite (TU), phyllo-telinite (PT), resinite (R), feldspar (Fs) (polarized reflected light) 200×; (C) Sporinite or alginite? (reflected, blue fluorescent, over 450X); (D) Animal remains in coaly shale (marked with arrows) - probably insect wings (reflected light, blue fluorescent, 200×); (E) Fusinite (F), semifusinite (sF) and funginite (Fu) in coaly layers enriched in organic material (polarized reflected light, 200×); (F) Coal in situ ventilation layers enriched with ulminite (U) and macrinite (Ma) (polarized reflected light, 450×).

Table 2. The major statistical parameters of the coal reflectogram.

\begin{tabular}{cccccccccccc}
\hline Sample & $\begin{array}{c}\mathbf{R}_{\mathbf{r}}^{\mathbf{0}} \\
\mathbf{( \% )}\end{array}$ & $\mathbf{n}$ & $\begin{array}{c}\text { stdv } \\
\mathbf{( \% )}\end{array}$ & $\mathbf{A}$ & $\mathbf{A}_{\text {st }}$ & $\mathbf{K}$ & $\mathbf{K}_{\text {st }}$ & $\begin{array}{c}\mathbf{R}_{\text {teor }} \\
(\mathbf{\%})\end{array}$ & $\begin{array}{c}\mathbf{R}_{\text {emp }} \\
(\mathbf{\%})\end{array}$ & $\begin{array}{c}\mathbf{Z} \\
(\mathbf{\%})\end{array}$ \\
\hline Coal from La Cumbre deposit & $\mathbf{0 . 3 9}$ & 110 & 0.03 & 0.4486 & 0.748 & -0.265 & -0.463 & 0.19 & 0.10 & $\mathbf{6 . 1}$ \\
\hline
\end{tabular}

Explanations: $\mathrm{R}_{\mathrm{r}}{ }^{\mathrm{O}}$ - the random reflectance of colotelinite, $\mathrm{n}$-number of measurements, stdv-standard deviation, A-skewness, $\mathrm{A}_{\mathrm{st}}$-standardized skewness, $\mathrm{K}$-kurtosis (flattening distribution), $\mathrm{K}_{\mathrm{st}}$-standardized kurtosis, $\mathrm{R}_{\text {teor }}$ - theoretical range on the reflectogram, $\mathrm{R}_{\mathrm{emp}}$ - empirical range, $\mathrm{Z}$-coefficient of variation (in \%).

Table 3. The petrographic composition of coaly shale. Summary percentages of each group of macerals and other petrographic components (minerals) are indicated in bold.

\begin{tabular}{ccccccc}
\hline Macerals (Code) & $\mathbf{1}$ & $\mathbf{2}$ & $\mathbf{3}$ & $\mathbf{4}$ & $\mathbf{5}$ & Average \\
\hline textinite (T) & 5.6 & 7.3 & 5.2 & 5.4 & 6.0 & 5.9 \\
ulminite (U) & 14.2 & 14.8 & 16.2 & 13.0 & 13.4 & 14.3 \\
corpogelinite (CG) & 1.0 & 0.8 & 0.5 & 1.5 & 1.0 & 1.0 \\
densinite (D) & 8.4 & 8.6 & 9.5 & 7.1 & 8.2 & 8.4 \\
$\sum$ huminite (H) & $\mathbf{2 9 . 2}$ & $\mathbf{3 1 . 5}$ & $\mathbf{3 1 . 4}$ & $\mathbf{2 7 . 0}$ & $\mathbf{2 8 . 6}$ & $\mathbf{2 9 . 5}$ \\
sporinite (Sp) & rare & rare & rare & rare & rare & rare \\
alginite (Al) & 0.0 & 0.0 & 0.0 & rare & 0.0 & rare \\
\hline
\end{tabular}


Table 3. Cont

\begin{tabular}{ccccccc}
\hline Macerals (Code) & $\mathbf{1}$ & $\mathbf{2}$ & $\mathbf{3}$ & $\mathbf{4}$ & $\mathbf{5}$ & Average \\
\hline resinite (R) & 3.5 & 4.0 & 3.1 & 3.7 & 3.0 & 3.5 \\
fluorinite (Fl) & 1.0 & 0.0 & 0.7 & 1.2 & 2.0 & 1.0 \\
cutinite (K) & 0.5 & 0.5 & 1.0 & 0.0 & 0.5 & 0.5 \\
fluorinite (Fl) & 1.7 & 1.5 & 2.1 & 1.5 & 1.5 & 1.7 \\
liptodetrinite (Ld) & 1.3 & 1.3 & 0.5 & 2.3 & 1.1 & 1.3 \\
$\sum$ liptinite (L) & $\mathbf{8 . 0}$ & $\mathbf{7 . 3}$ & $\mathbf{7 . 4}$ & $\mathbf{8 . 7}$ & $\mathbf{8 . 1}$ & $\mathbf{7 . 9}$ \\
fusinite (F) & 0.0 & 0.0 & 0.0 & 0.0 & 0.0 & 0.0 \\
semifusinite (Sf) & 3.5 & 3.5 & 3.1 & 3.9 & 3.5 & 3.5 \\
funginite+secretinite (Fu+S) & 3.5 & 2.8 & 2.1 & 4.1 & 4.4 & 3.4 \\
macrinite (Ma) & 0.5 & 0.5 & 0.7 & 0.5 & 0.5 & 0.5 \\
inertodetrinite (Id) & 1.1 & 1.0 & 0.8 & 1.5 & 1.2 & 1.1 \\
$\sum$ inertinite (I) & $\mathbf{8 . 6}$ & $\mathbf{7 . 8}$ & $\mathbf{6 . 7}$ & $\mathbf{1 0 . 0}$ & $\mathbf{9 . 6}$ & $\mathbf{8 . 5}$ \\
$\sum$ organic matter (OM) & $\mathbf{4 5 . 8}$ & $\mathbf{4 6 . 6}$ & $\mathbf{4 5 . 5}$ & $\mathbf{4 5 . 7}$ & $\mathbf{4 6 . 3}$ & $\mathbf{4 6 . 0}$ \\
quartz (Q) & 5.2 & 4.9 & 4.7 & 5.3 & 5.7 & 5.2 \\
feldspars (Fs) & 3.8 & 3.5 & 3.9 & 3.0 & 4.5 & 3.7 \\
clay minerals (Clm) & 35.0 & 34.4 & 35.3 & 36.4 & 33.3 & 34.9 \\
pyrite (P) & 8.7 & 9.0 & 9.0 & 8.5 & 8.7 & 8.8 \\
others minerals (Om) & 1.5 & 1.6 & 1.6 & 1.1 & 1.5 & 1.5 \\
$\sum$ minerals (MM) & $\mathbf{5 4 . 2}$ & $\mathbf{5 3 . 4}$ & $\mathbf{5 4 . 5}$ & $\mathbf{5 4 . 3}$ & $\mathbf{5 3 . 7}$ & $\mathbf{5 4 . 0}$ \\
\hline
\end{tabular}

\subsection{Facies Analysis}

The results of the petrographic analysis are presented in Diessel's diagram, partially modified (gelification index-GI and preserved plant tissue index-TPI) by Kalkreuth et al. [29] and also slightly changed for groundwater horizon location index (GWI) and vegetation index (VI) according to the names of macerals, partly according to Gruber and Sachsenhofer [30] (Figure 6). The intersection points are on the borderline between two fields: the lake facies (limnic) and periodically flooded forest (dry forest and wet forest swamp). The overlapping of these two facies created by the lake littoral zone (probably a maritime coastal lake) and the floodplain of the river flowing into the lake may be characterized by: (1) periodic longer run-off during flooding (high GI illustrating the degree of gelification) associated with periodic storms and climatic rising of rivers and (2) frequent and strong periodic flooding of the lake, the flow of which may transport tree fragments (preserved layers of textinite and ulminite) and fine plant detritus (densinite) together with clay and granular suspensions of minerals that were embedded later in the littoral part of the lake or at the marginal part of the floodplain. This is well confirmed by the low level of aerobic decomposition of deposited plant material, i.e., trees and coarse-grained detritus (TPI).

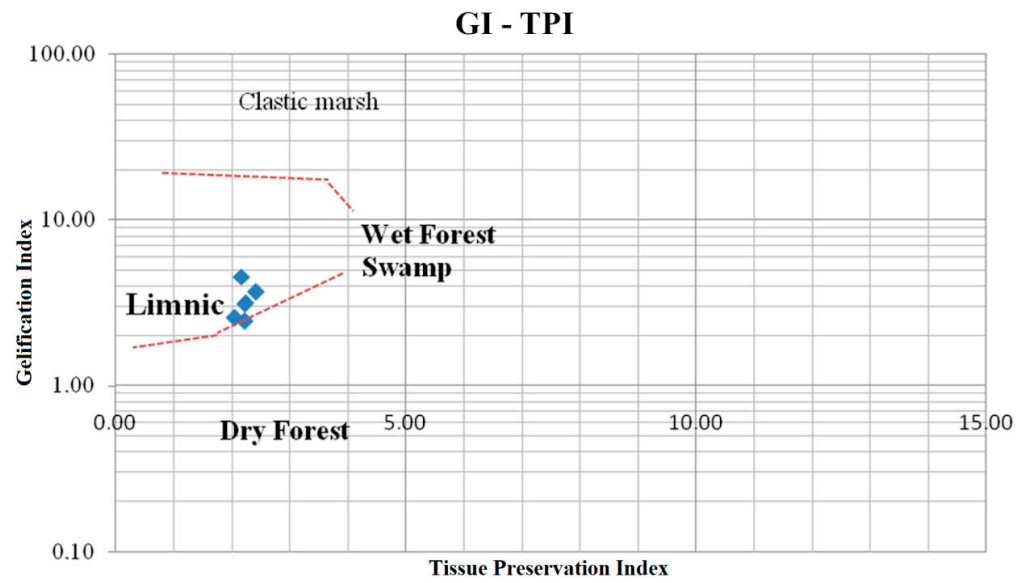

Figure 6. Position of the coaly shales from La Cumbre deposit in Diessel's facies diagram [31] (modified by Kalkreuth et al. [29]). 
Similar locations of analytical points on the GWI and VI facies diagram are also observed (Figure 7). The results indicate the transition environment between limnic and swamp zones. The proximity of the inundated marsh and inundated forest and, at a later stage, a typical swamp forest indicates the extreme part of the flood plain bordering with the lake's littoral area. However, this diagram provides a different interpretation of the sedimentation conditions of the plant material. It was drawn by Calder et al. [32] for the Cumberland Basin of Nova Scotia, Canada, taking into account the presence of several different zones of the coal seam and coal rocks, including the piedmont inflow fans at the lake border and the adjacent bogged floodplain. The outer zones of the fans were swamped by layered reservoirs, while the internal ones developed progressively from rheotrophic to vertical paludization of tropical peat bogs. Calder et al. [32] developed a scheme based on the same principles as Diessel's system [31], but with a different interpretation. Instead of GI, they used the GWI, which expresses the redox potential (Eh) of the environment and is modeled based on the VI, the secondary condition for identifying peat bog types. Both standards define the palaeoconditions of peat bogs in a way similar to marsh Miocene sediments and modern tropical wetland areas. According to Kalkreuth et al. [29], Wagner and Drobniak [39] and Flores et al. [40], it can be assumed that sedimentation conditions were characterized by a strongly irrigated environment, found between the lake (even the coastal sea) and the land with rheotropic supply.

Hence, both interpretations of the palaeoenvironment of the La Cumbre amber deposit are convergent. The palaeoenvironment likely comprised border zones of the lakes or even coastal seas making contact with the adjacent floodplains of the river that were heavily loaded with clastic material. However, the local development of piedmont fans was not excluded.

GWI - VI

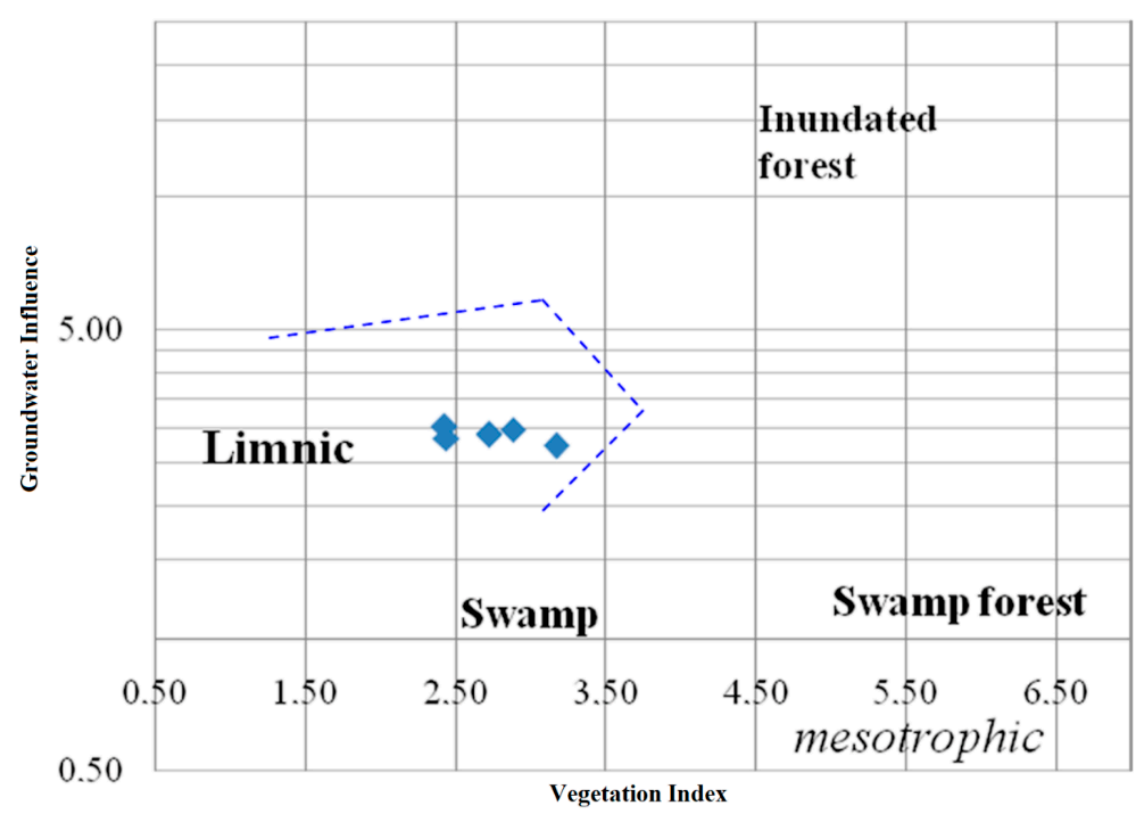

Figure 7. Position of the coaly shale from La Cumbre deposit on a facies diagram [32] (modified according to meta-lignite macerals).

\subsection{Dominican Amber Characteristics}

Fossil resins belong to the main components of the coaly shales and form at least two morphological forms: type I is detrital fossil resin, located in clay layers together with the detrital material (Figure 4A); type II comprises authigenic, flattened, droplet grains in coal layers (Figure 4C,D). The detrital fossil resin is transparent, yellow or yellow-brown and of different sizes.. The authigenic fossil resin (resinite) forms finer grains visible only under the microscope. It is colorless or yellow-brown. This type of resinite is mostly isotropic and only shows poor anisotropy locally, due to the presence of inclusions of 
clay minerals or flocs of poorly transformed cellulose from wood tissues. In the presence of UV light, it has a greenish color (Figure 4D).

The authigenic fossil resin (resinite) forms bead-like aggregates found in the central part of the carbon layers. The maximum axis length of the individual grains of resin ranges from 0.4 to $0.8 \mathrm{~mm}$. These are probably fragments of stems of high-stemmed plants, whereas the resin clusters are the remains of their resin channels in cross-sections, parallel to the long axis. It is also probable that this "resinous" plant material also includes juvenile, green plant stems or leaves, as indicated by poorly preserved fragments of cutinite and phlobaphinite found in close proximity to regular clusters of fossil resin (resinite).

As mentioned above, microhardness tests were performed only on the pieces of the detrital fossil resin (type I). The measured microhardness values $(\mathrm{n}=20)$ fluctuated from $19.87 \mathrm{kgf} / \mathrm{mm}^{2}\left(\mathbf{H}_{\mathrm{vmin}}\right)$ to $35.76 \mathrm{kgf} / \mathrm{mm}^{2}\left(\mathbf{H}_{\mathrm{vmax}} ; 194.86-350.69 \mathrm{MPa}\right)$. The average $\left(\mathbf{H}_{\mathbf{v a}}\right)$ value was $28.55 \mathrm{kgf} / \mathrm{mm}^{2}(279.98 \mathrm{MPa})$; $\mathrm{SD}=4.24 \mathrm{kgf} / \mathrm{mm}^{2}(41.58 \mathrm{MPa})$.

Raman spectroscopy (RS) analyses indicated the presence of two types of different resins containing aromatic moieties, for which fluorescence strongly affects the background of the spectra (Table 4 and Figure $8 \mathrm{~A}, \mathrm{~B}$ ). The small resinite grains (type II) measured with a 514.5-nm laser line additionally showed the presence of pyrite, whose diagnostic bands at 338, 374 and $425 \mathrm{~cm}^{-1}$ [54] were distinguished from the high background.

Table 4. Raman bands found in the RS spectra of two types of Dominican fossil resins (see Figure 8A,B) and their assignments [55-60].

\begin{tabular}{|c|c|}
\hline $\begin{array}{c}\text { Raman Bands } \\
{\left[\mathrm{cm}^{-1}\right]}\end{array}$ & Interpretation \\
\hline 1644 & $v_{\text {sym }} C=C$ non conjugated \\
\hline 1440 & $\delta\left(\mathrm{CH}_{2}\right), \delta\left(\mathrm{CH}_{3}\right)$ scissors \\
\hline 1407 & $\delta\left(\mathrm{CH}_{2}\right), \delta\left(\mathrm{CH}_{3}\right)$ \\
\hline 1358 & $\delta\left(\mathrm{CH}_{2}\right), \delta\left(\mathrm{CH}_{3}\right)$ \\
\hline 1329 & $\delta\left(\mathrm{CH}_{2}\right), \delta\left(\mathrm{CH}_{3}\right)$ \\
\hline 1308 & $\delta\left(\mathrm{CH}_{2}\right), \delta\left(\mathrm{CH}_{3}\right)$ twisting \\
\hline 1284 & $\delta\left(\mathrm{CH}_{2}\right), \delta\left(\mathrm{CH}_{3}\right)$ \\
\hline 1201 & $\delta(\mathrm{CCH}), \delta(\mathrm{C}-\mathrm{O})$ \\
\hline 1135 & $v(\mathrm{CC})$ ring breathing \\
\hline 1104 & $v(C-C)$ \\
\hline 1006 & $v(C C)$ aromatic \\
\hline 978 & $\rho\left(\mathrm{CH}_{2}\right), \rho\left(\mathrm{CH}_{3}\right)$ \\
\hline 945 & $\rho\left(\mathrm{CH}_{2}\right), \rho\left(\mathrm{CH}_{3}\right)$ \\
\hline 883 & $\rho\left(\mathrm{CH}_{2}\right), v(\mathrm{COC})$ \\
\hline 823 & $\rho\left(\mathrm{CH}_{2}\right)$ \\
\hline 744 & $v(C C)$ isolated \\
\hline 721 & $v(C C)$ isolated \\
\hline 695 & $v(C C)$ isolated \\
\hline 639 & $v(\mathrm{C}-\mathrm{S}), \mathrm{TiO}_{2}$ (anatase) \\
\hline 555 & $\delta(\mathrm{CCO})$ \\
\hline 525 & $\delta(\mathrm{COC})$ in plane deformation, sulfur compounds \\
\hline 440 & sulfur compounds, $\mathrm{TiO}_{2}$ \\
\hline 373 & sulfur compounds, $\mathrm{TiO}_{2}$ \\
\hline 317 & sulfur compounds \\
\hline
\end{tabular}

These spectra with extremely high backgrounds showed emerging bands typical for the condensed aromatic rings, as well as carbon polymorphic forms found in the positions near $1594 \mathrm{~cm}^{-1}$ and $1369 \mathrm{~cm}^{-1}$ (Table 4 and Figure 8B). They likely indicate the presence of resinite (type II). It is noted that the condensation process of aromatic carbon systems can be precisely monitored by RS [41,61-65]. The fossil resins with a tubular shape showed a spectrum with diagnostic bands at about $1586 \mathrm{~cm}^{-1}$ and $1380 \mathrm{~cm}^{-1}$. They are not fully formed, but rather disordered, indicated by broad half widths of the 
bands. The fossil resin is likely accompanied by minerals such as anatase, which was indicated by the presence of a band at $141 \mathrm{~cm}^{-1}$ [66].

The spectrum of larger fossil resin pieces (type I) measured by laser light at the 1064-nm wavelength indicated the presence of numerous bands (Table 4 and Figure 8A). The most intensive were found at 1440 and $1644 \mathrm{~cm}^{-1}$, attributed to $\delta\left(\mathrm{CH}_{2}\right), \delta\left(\mathrm{CH}_{3}\right)$ and $v(\mathrm{C}=\mathrm{C})$ vibrations, respectively [56]. The less intensive bands at 1329 and $1358 \mathrm{~cm}^{-1}$ were also due to $\delta\left(\mathrm{CH}_{2}\right)$ and $\delta\left(\mathrm{CH}_{3}\right)$. The vibrations of $v(\mathrm{C}-\mathrm{C})$ were proved by the presence of the bands at 744,721 and $695 \mathrm{~cm}^{-1}$ [56].
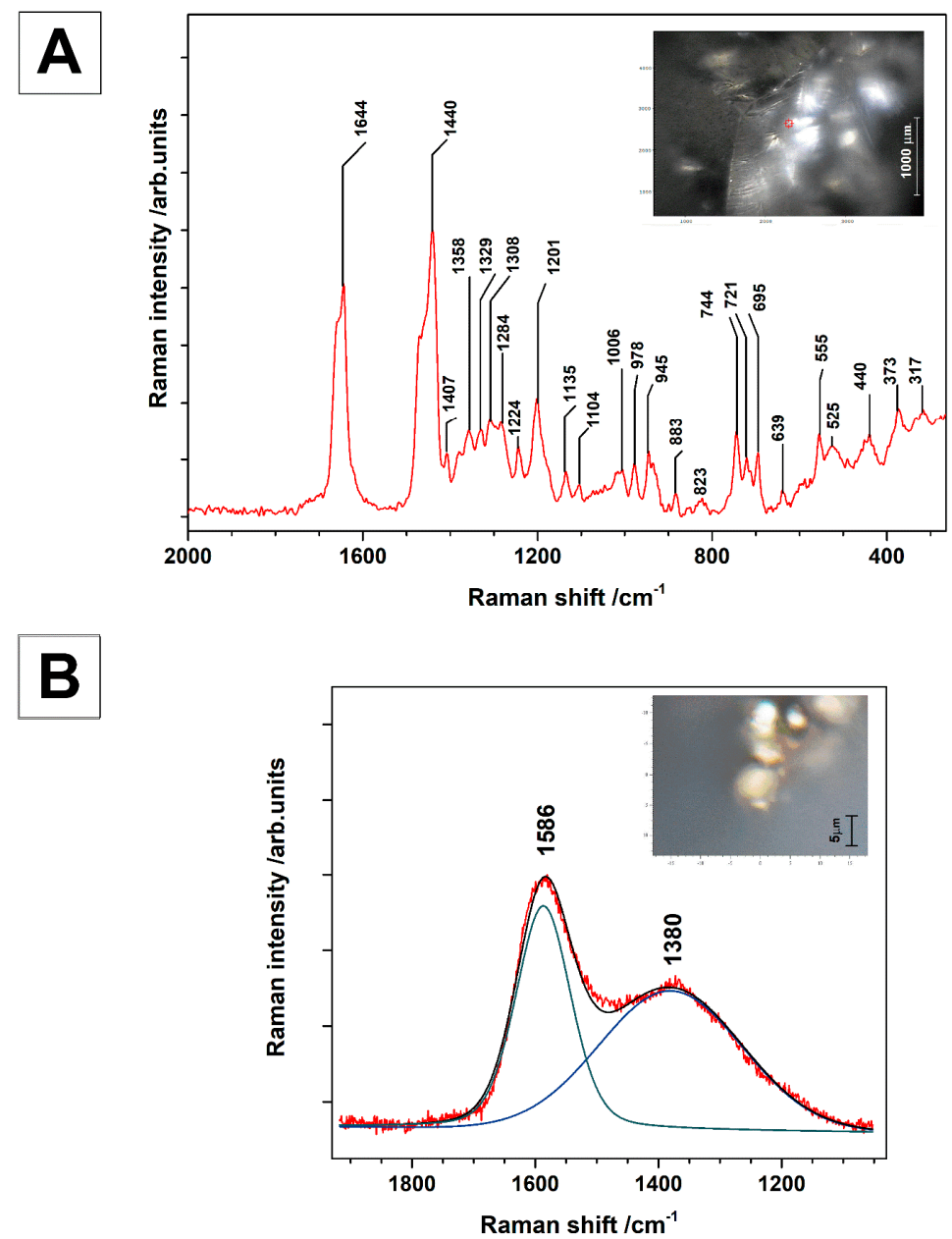

Figure 8. The RS spectra of two types of Dominican fossil resins; (A) type I fossil resin; (B) type II fossil resin.

Significantly higher intensities of bands at 744 and 695 compared to $721 \mathrm{~cm}^{-1}$ indicate relatively low maturity of type I fossil resin [56]. The weak band at $883 \mathrm{~cm}^{-1}$ due to out-of-plane v(COC) and $\rho\left(\mathrm{CH}_{2}\right)$ vibrations in the methylene group [56] is clearly marked in the spectrum of this resin. Interestingly, in the Raman spectrum, there are also bands in the region of 550 to $440 \mathrm{~cm}^{-1}$, which may be associated with the S-S sulfur vibration $[55,60]$, suggesting the presence of sulfides in this resin type. In the same range, bands of a low intensity with maxima near 638,516 and $397 \mathrm{~cm}^{-1}$ and 610 , 445 and $241 \mathrm{~cm}^{-1}$ are also visible, probably due to the presence of anatase and rutile [57]. On the whole, the Raman spectrum of this type I fossil resin is very similar to that obtained for other resins from Santiago and Hato Mayor Province (Dominican Republic) presented by Naglik et al. [67]. Based on the similarity of the above spectra, it can be concluded that these resins originate from the same botanical source, namely plants of the genus Hymenaea (Fabaceae) and that they belong to chemical class Ic $[5,68]$. 


\section{Discussion}

The analytical material from the La Cumbre amber deposit of the NMD in the Dominican Republic was recognized as dark gray, poorly sorted coaly shales of aleurite-pelite fraction. Nearly the whole profile of the La Toca Formation (Figure 2) is composed of marine sediments. Some layers with fragments of lignite [48] and numerous pieces of fossil resins are found only in its upper parts and were probably a short-term deposit in the marine environment near the river delta, as suggested by Redmond [49] and Iturralde-Vinent [13].

The texture of the coaly shale is stratified, underlined by alternating layers of clay, coal, mudstone and brown coal (meta-lignite). The petrography indicated that it is typical lake-swamp sediment. Over time, the layered sedimentation was compressed by overlying sediments and cracked due to increasing pressure. This is a mixture of clay minerals, illite and kaolinite, detrital quartz, weathered feldspars and accessory amphiboles, as well as zircon and anatase. The matrix of the sediment is strongly enriched with coal dust and plant detritus and an abundance of fossil resin grains. In such specific environment, products were also found that formed as a result of chemical sedimentation, such as calcite accompanied by rosette clusters of gypsum.

The relatively small thickness of the alternating layers (from $1.5 \mathrm{~cm}$ to sub-mm), repeated many times in the profile of the rock series and could be evidence of a shallow basin and the calm sedimentation being disturbed from time to time by the influx of thicker detrital material from the nearby land. As a result of the sinking of this material within unconsolidated sediments, the formation of load casts probably occurred, which in turn caused the interruption of the continuity of the original layers. Hence, it is very probable that the source area might be the shallow floodplain and the shore of a permanent lake, cyclically enriched with a wealth of detrital material, both mineral and organic, supplied by rivers.

The existence of the layers with the coal of humotelinite petrographic type (semibright coal-meta-lignite, also technologically low rank), occurring alternately with layers enriched in fusinite, semifusinite, macrinite and secretinite (Figures $4 \mathrm{~F}$ and $5 \mathrm{E}, \mathrm{F}$ ), provides a significant source of information on the petrogenesis. The presence of these macerals indicates progressive changes of the sedimentation environment from oxidizing to reducing, which is typical for a dynamic water regime in a floodplain, for the littoral zone of lake basins or for the periodic floodplain regime, e.g., in the upper part of a lake delta (limnic fan).

The reflectogram of coal being a component of coaly shale and some statistical parameters of the random reflectance (Table 2) indicate a normal Gaussian distribution. This is typical of phytogenic material that has "undergone" coalification under normal geothermal conditions, i.e., at increasing temperature and static pressure in geological time, with a geothermal gradient of $10-30{ }^{\circ} \mathrm{C} / \mathrm{km}$, characteristic for coaly deposits (excluding contact metamorphism and weathering conditions). The coal reflectogram is slightly skewed right $\left(\mathrm{A}_{\mathrm{st}}\right.$ —standardized skewness and A-skewness $\left.<2\right)$ and weakly flattened ( $\mathrm{K}$-kurtosis and $\mathrm{K}_{\mathrm{st}}$ - standardized kurtosis, 2), which suggests that coal has still been undergoing further "normal" coalification, i.e., with the probable influence of mainly thermal and moderately dynamic metamorphism. The random reflectance of eu-ulminite B $(0.39 \%)$ indicates the occurrence of meta-lignite. Based on the international classification $[69,70]$, this corresponds to the transition zone from meta-lignite (low-rank B) to subbituminous coal (low-rank A), but with an indication of the meta-lignite stage.

The nature of the sedimentary environment of the La Cumbre deposit was also assessed using modified diagrams by Diessel [31], Calder et al. [32], Kalkreuth et al. [29], Gruber and Sachsenhofer [30] and others for marsh (coaly) Miocene sediments. The projections of data points in both diagrams are clustered on the border between the lake facies (limnic) and periodically flooded area (dry forest and wet forest swamp).

The two forms of fossil resin (type I and type II), identified in the sediment are fundamentally different in terms of their size, morphology, proportions of mineral and organic inclusions, as well as the state of preservation. The average microhardness value of Dominican amber from La Cumbre 
$\left(28.55 \mathrm{~kg} / \mathrm{mm}^{2} ; 279.98 \mathrm{MPa}\right)$ makes it very close to Baltic amber $\left(27-30 \mathrm{kgf} / \mathrm{mm}^{2} ; 265-295 \mathrm{MPa}\right)$. However, Dominican amber is more brittle than Baltic amber. The microhardness of Dominican amber, especially the fossil resins from Santiago Province, is quite high in spite of the young age and similarity to other Miocene fossil resins from Mexico and Indonesia. The fossil resins were deposited and buried in reducing environmental conditions, possibly during increased volcanic activity (confirmed in the case of Indonesia; [9,71]). The cooling and pre-treatment during the water transport of resins to the basin probably also influenced the high hardness of the material [10].

The detrital fossil resin (type I) forms poor to well-rounded and poorly sorted pieces. The morphological and granulometric variabilities indicate a relatively short transport of this material, presumably across a calm river stream or laminar flow. The type II of resinite is a strongly altered organic material, occurring as drip-like forms in carbon layers, clearly directed and flattened. The transportation and subsequent transformations of this resin in the specific conditions of the sedimentation basin likely caused certain changes in fossil resin chemical composition, indicated by the vivid greenish colors of fluorescence. The spectroscopic data also indicated further differences in its composition, i.e., in its sulfur content and the position of this element in its structure. Its low degree of maturity compared to some Dominican (especially blue amber) and Mexican fossil resins [56,67] found by RS suggests that it was delivered to the basin later than plant detritus and type II resinite.

The source of sulfur in the large pieces of fossil resin (type I) may originate from various insects trapped and degraded in the resin [23,68,72-74]. The chemical preservation of plants and insects in natural resins and later the diagenesis of their tissues may result in the enrichment of these resins with sulfur compounds [75-77]. On the other hand, the contamination of the resin with sulfur may occur during its burial processes (e.g., sulfur-bearing minerals from the soil), or may be the effect of volcanic or forest fire ashes [13]. Sulfur in the resin could also be associated with plants. In general, disulfide bonds stabilize the structures of proteins in plants [78], so their presence in the resins may be treated as an indicator of the initial stage of resin formation. However, the most probable source of sulfur could be marine sediments. In an anoxic condition, sulfate is reduced to organic or inorganic sulfides by sulfate-reducing bacteria [76]. These compounds likely react with functionalized groups in organic matter during diagenesis. The iron species compete in this reaction. The euxinic conditions and the absence of iron species favor the incorporation of sulfur in organic matter. This reaction may occur in an intramolecular fashion, leading to the formation of low molecular weight sulfur compounds or, in an intermolecular fashion, generating sulfur-rich macromolecular aggregates [76].

The influence of geological factors on the sulfur content in the structure of the fossil resin is also confirmed by the presence of pyrogenic and detrital quartz grains. The mineral composition of detrital material (quartz, feldspar, mica group minerals) and the characteristic elongated shape of grains with sharp edges, as well as the presence of anatase, may indicate a mixed source of origin of that material. The host rocks of the detrital sediments could be granite-type acidic igneous rocks (tonalite), occurring nearby the sedimentation basin, and their volcanic equivalents or pyroclastic rocks (tuffs) may contain typical pyrogenic quartz [13] and metamorphic rocks. These rocks can be found in the Pedro Garcia Formation below the La Toca Formation [13]. In addition, there are subvolcanic rocks of the andesite and basalt type. It is known that sulfur emissions from basalt lava have caused mass extinctions and climate change in the past [79]. The degree of transformation of some feldspar and mica grains seems to be quite advanced. The product of these transformations, i.e., mainly kaolinite, indicates an oxidizing and strongly acidic environment. In turn, the reduction conditions and the relatively low $\mathrm{pH}$ is likely indicated by the presence of numerous grains of framboidal pyrite. Most often, they were accumulated within the clay-coal layers. Pyrite forms either individual grains or different sizes of its aggregates. This proves the euxinic conditions of the sediment formation, i.e., an oxygen-depleted environment in the lower parts of the profile, with the simultaneous existence of hydrogen sulfide originating from the decomposition of organic matter [80,81]. Pyrite framboids have also been found in small resinite grains (type II) from the NMD. Presumably, the accumulation of iron sulfide is the result of the permineralization of microorganisms or some minerals (e.g., quartz) 
before they were embedded in the resin. Such a process is a special case of biological preservation called double fossilization [82].

\section{Conclusions}

The amber-bearing coaly shales from the La Cumbre deposit consist mainly of plant detritus, clay minerals such as illite and kaolinite, pyrogenic quartz, weathered feldspars and subordinate amphiboles, pyrite, calcite, rosette clusters of gypsum, zircon, and anatase. Such a strongly varied composition of the rocks was interpreted as a mixture of land-derived material and components formed in situ in the marine basin. The petrographic features of these sediments seem to be characteristic of a lake-swamp environment.

The reconstruction of the palaeoenvironment of the La Cumbre deposit based on the facial analyses of the rocks indicated that the environment of marine sedimentation could be transitional between a shallow maritime lake and periodically flooded plain.

The presence of a xylite-rich type of coal (stratified and strongly gelified) with layers enriched with macerals, such as fusinite, semifusinite, macrinite, and secretinite, indicates changes in the sedimentation environment from oxidizing to reducing, which is characteristic for a coastal-littoral zone of a lake basin or floodplain regime (e.g., limnic fan).

The fossil resin features, such as relatively high microhardness, sulfur compounds in their composition and the wealth of gelified organic material, indicate mostly a reducing sedimentation environment and the probable influence of volcanic activity on the La Cambre coal series surroundings. The probable source of sulfur in amber might be organic inclusions (animals and plants) and marine sediments (e.g., sulfates).

Author Contributions: P.S., L.N.-N., M.W., M.D.-S., M.M.-S. and P.D. designed the experiments, interpreted the data, wrote the paper and prepared figures and photographs. A.W.-B. performed the experiments and interpreted the RS data. C.G. and E.G. provided rock samples for research and information about the geology of the tested region of the Dominican Republic. All authors have read and agreed to the published version of the manuscript.

Funding: This research was funded by AGH University of Science and Technology, grant number 16.16.140.315 and the Polish Geological Institute-National Research Institute, research project number 62.9012.1908.00.0. The APC was funded by AGH University of Science and Technology, grant number 16.16.140.315 and the Polish Geological Institute-National Research Institute, research project number 62.9012.1908.00.0.

Acknowledgments: Authors greatly thank Jorge Caridad from Dominican Republic for providing resin samples for testing. The manuscript was proofread by Academic Proofreading Service Ltd. We thank the anonymous reviewers for their constructive comments and the editor for handling the paper.

Conflicts of Interest: The authors declare no conflict of interest.

\section{References}

1. Tomkeieff, S.I. Coals and Bitumens and Related Fossil Carbonaceous Substances: Nomenclature and Classification, 1st ed.; Pergamon Press: Oxford, UK, 1954.

2. Langenheim, J.H. Plant Resins: Chemistry, Evolution, Ecology, and Ethnobotany; Timber Press: Portland, OR, USA, 2003.

3. Anderson, K.B.; Winans, E.E.; Botto, R.E. The nature and fate of natural resins in the geosphere. II. Identification, classification, and nomenclature of resinites. Org. Geochem. 1992, 18, 829-841. [CrossRef]

4. Cunningham, A.; West, P.R.; Hammond, G.S.; Langenheim, J.H. The existence and photochemical initiation of free radicals in Hymenaea trunk resins. Phytochemistry 1977, 16, 1442-1443. [CrossRef]

5. Anderson, K.B. New evidence concerning the structure, composition, and maturation of class I (polylabdanoid) resinites. In Amber, Resinite and Fossil Resins; Anderson, K.B., Crelling, J., Eds.; American Chemical Society Symposium Series: Washington, DC, USA, 1995; Volume 617, pp. 105-129. [CrossRef]

6. Poinar, G.O., Jr.; Mastalerz, M. Taphonomy of fossilised resins: Determining the biostratinomy of amber. Acta Geol. Hisp. 2000, 35, 171-182.

7. Winkler, W.; Kirchner, E.C.; Asenbaum, A.; Musso, M. A Raman spectroscopic approach to the maturation process of fossil resins. J. Raman Spectrosc. 2001, 32, 59-63. [CrossRef] 
8. Jehlička, J.; Jorge Villar, S.E.; Edwards, H.G.M. Fourier transform Raman spectra of Czech and Moravian fossil resins from freshwater sediments. J. Raman Spectrosc. 2004, 35, 761-767. [CrossRef]

9. Naglik, B.; Kosmowska-Ceranowicz, B.; Natkaniec-Nowak, L.; Drzewicz, P.; Dumańska-Słowik, M.; Matusik, J.; Wagner, M.; Milovsky, R.; Stach, P.; Szyszka, A. Evolutionary history of fossil resin from Jambi Province (Sumatra, Indonesia) based on physico-chemical studies. Minerals 2018, 8, 95. [CrossRef]

10. Stach, P.; Martinkutè, G.; Šinkūnas, P.; Natkaniec-Nowak, L.; Drzewicz, P.; Naglik, B.; Bogdasarov, M. An attempt to correlate the physical properties of fossil and subfossil resins with their age and geographic location. J. Polym. Eng. 2019, 39, 716-728. [CrossRef]

11. Kosmowska-Ceranowicz, B. Succinite and some other fossil resins in Poland and Europe (deposits, finds, features and differences in IRS). Estud. Mus. Cienc. Nat. Alava 1999, 14, 73-117.

12. Zherikhin, V.V.; Eskov, K.Y. Mesozoic and Lower Tertiary resins in former USSR. Estud. Mus. Cienc. Nat. Álava 1999, 14, 119-131.

13. Iturralde-Vinent, M.A. Geology of the amber-bearing deposits of the Greater Antilles. Caribb. J. Sci. 2001, 37, 141-167.

14. Roghi, G.; Ragazzi, E.; Gianolla, P. Triassic amber of the southern Alps (Italy). Palaios 2006, 21, $143-154$. [CrossRef]

15. Bogdasarov, M.A. Mineralogy of fossil resins in Northern Eurasia. Geol. Ore Depos. 2007, 49, 630-637. [CrossRef]

16. Bogdasarov, M.A. Amber and Others Fossil Resins of Eurasia. Ph.D. Thesis, Brest State A.S. Pushkin University, Pushkin, Russia, 2010. (In Russian)

17. Penney, D. Dominican amber. In Biodiversity of Fossils in Amber from the Major World Deposits; Penney, D., Ed.; Siri Scientific Press: Manchester, UK, 2010; pp. 23-42.

18. Ragazzi, E.; Schmidt, A.R. Amber. In Encyclopedia of Geobiology; Reitner, J., Thiel, V., Eds.; Springer: Berlin/Heidelberg, Germany, 2011; pp. 24-36. [CrossRef]

19. Anderson, K.B. The nature and fate of natural resins in the geosphere-VII. A radiocarbon $\left({ }^{14} \mathrm{C}\right)$ age scale for description of immature natural resins: An invitation to scientific debate. Org. Geochem. 1997, 25, 251-253. [CrossRef]

20. Kosmowska-Ceranowicz, B. Bursztyn i inne żywice kopalne. Żywice kopalne Ameryki Środkowej: Bursztyn meksykański i bursztyn dominikański/Amber and Other Fossil Resins. Fossil resins of Central America: Mexican amber and Dominican amber. Polski Jubiler 2000, 1, 18-20. (In Polish)

21. Kosmowska-Ceranowicz, B. Bursztyn w Polsce i na Świecie/Amber in Poland and in the World, 1st ed.; Warsaw University Press: Warsaw, Poland, 2012; ISBN 978-83-235-0774-1.

22. Poinar, G.O., Jr.; Poinar, R. The Amber Forest: A Reconstruction of a Vanished World; Princeton University Press: Princeton, NJ, USA, 1999; ISBN 0-691-02888-5.

23. Poinar, G.O., Jr. Palaeoecological perspectives in Dominican amber. Ann. Soc. Entomol. Fr. 2010, 46, $23-52$. [CrossRef]

24. Matuszewska, A.; Gołąb, A.; Salomon, A. Mikrotwardość bursztynu i jego imitacji/Microhardness of amber and its imitations. Polski Jubiler 2002, 1, 26-29. (In Polish)

25. Matuszewska, A.; Gołąb, A. Próba wykorzystania parametru mikrotwardości żywic kopalnych i sztucznych, jako cechy klasyfikacyjnej/An attempt at using the parameter of the microhardness of fossil and artificial resins as a classification feature. Bursztynisko 2008, 31, 56-61, (In Polish and in English).

26. Matuszewska, A. Bursztyn (Sukcynit), Inne Żywice Kopalne, Subfosylne $i$ Wspótczesne/Amber (Succinite) and Other Modern, Subfossil and Fossil Resins, 1st ed.; Oficyna Wydawnicza Wacław Walasek: Katowice, Poland, 2010; ISBN 978-83-60743-34-8. (In Polish)

27. Iturralde-Vinent, M.A.; MacPhee, R.D.E. Age and palaeogeographical origin of Dominican amber. Science 1996, 273, 1850-1852. [CrossRef]

28. Bachmann, R. The Caribbean Plate and the Question of its Formation; University of Mining and Technology, Institute of Geology, Department of Tectonophysics: Freiberg, Germany, 2001. Available online: http: //www.geo.tu-freiberg.de/hydro/oberseminar/pdf/Raik\%20Bachmann.pdf (accessed on 15 March 2020).

29. Kalkreuth, W.; Kotis, T.; Papanicolaou, C.; Kokkinalis, P. The geology and coal petrology of a Miocene lignite profile at Meliadi Mine, Katerini, Greece. Int. J. Coal Geol. 1991, 17, 51-67. [CrossRef]

30. Gruber, W.; Sachsenhofer, R. Coal deposition in the Noric Depression (Eastern Alps): Raised and low-lying mires in Miocene pull-apart basins. Int. J. Coal Geol. 2001, 48, 89-114. [CrossRef] 
31. Diessel, C.F.K. On the correlation between coal facies and depositional environments. In Advances in the Study of the Sydney Basin, Proceedings of the Twentieth Symposium Department of Geology; University of Newcastle (N.S.W.): Newcastle, Australia, 1986; pp. 11-22.

32. Calder, J.; Gibling, M.R.; Mukhopadhyay, P.K. Peat formation in a Westphalian B piedmont setting, Cumberland Basin, Nova Scotia: Implication for the maceral-base interpretation or rheotrophic and raised paleomires. Bull. Soc. Géol. Fr. 1991, 162, 283-298.

33. Stach, E.; Mackowsky, M.-T.; Teichmüller, M.; Taylor, G.H.; Chandra, D.; Teichmüller, R. Stach's Textbook of Coal Petrology, 3rd ed.; Gebrüder Borntraeger: Berlin/Stuttgart, Germany, 1982.

34. Kalkreuth, W.; Leckie, D. Sedimentological and petrographical characteristic of Cretaceous strandplain coals; a model for coal accumulation from the North American Western Interior Seaway. Int. J. Coal Geol. 1989, 12, 381-424. [CrossRef]

35. Diessel, C.F.K.; Boyd, R.; Wadsworth, J.; Leckie, D.; Chalmers, G. On balanced and unbalanced accummulation/peat accumulation ratios in the Cretaceous coals from Gates Formation, Western Canada, and their sequence-stratigraphic significance. Int. J. Coal Geol. 2000, 43, 143-186. [CrossRef]

36. Buillit, N.; Lalier-Verges, E.; Pradier, B.; Nicolas, G. Coal petrographic genetic units in deltaic-plain deposits of the Campanian Mesa Verde Group (New Mexica, USA). Int. J. Coal Geol. 2002, 52, 93-110. [CrossRef]

37. Potter, J.; McIlreath, I.; Natras, T. Lithotypes, Macerals and Coal Facies Studies of Lower Cretaceous Medicine River Coals in South Central Alberta: Applications in CBM Exploration, Depositional Environments and Tectonic History Studies. In Proceedings of the 2008 CSPG-CSEG-CWLS Convention: Back to exploration, Calgary, Canada, 12-15 May 2008; pp. 777-780.

38. Potter, J.; Beaton, A.; McDougall, W.; Namburdiri, E.M.V.; Vigrass, L.W. Depositional environments of the Hart coal zone (Paleocene), Willow Bunch Coalfield, southern Saskatchewan, Canada from petrographic, palynological, palaeobotanical, mineral and trace elemements studies. Int. J. Coal Geol. 1991, 19, $253-281$. [CrossRef]

39. Wagner, M.; Drobniak, A. Petrology of the so-called cuboidal clays from the Belchatow lignite deposit. Prace Geol. PAN 2000, 147, 73-97. (In Polish, English summary)

40. Flores, D. Organic facies and depositional palaeonvironment of lignites from Rio Maior Basin (Portugal). Int. J. Coal Geol. 2002, 48, 181-195. [CrossRef]

41. Wilkins, R.W.T.; Sherwood, N.; Li, Z. RaMM (Raman maturity method) study of samples used in an interlaboratory exercise on a standard test method for determination of vitrinite reflectance on dispersed organic matter in rocks. Mar. Pet. Geol. 2018, 91, 236-250. [CrossRef]

42. ISO 7404-5. Methods for the Petrographic Analysis of Coals-Part 5: Method of Determining Microscopically the Reflectance of Vitrinite; International Organization for Standardization: Geneva, Switzerland, 2009; p. 14.

43. ISO 7404-3. Methods for the Petrographic Analysis of Coals_Part 3: Method of Determining Maceral Group Composition; International Organization for Standardization: Geneva, Switzerland, 2009; p. 7.

44. ISO 6507-1. Metallic Materials_Vickers Hardness Test_Part 1: Test Method; International Organization for Standardization: Geneva, Switzerland, 2018.

45. De Zoeten, R.; Mann, P. Structural geology and Cenozoic tectonic history of the Central Cordillera Septentrional, Dominican Republic. In Geologic and Tectonic Development of the North America-Caribbean Plate Boundary in Hispaniola; Mann, P., Draper, G., Lewis, J.F., Eds.; Geological Society of America Special Paper: Boulder, CO, USA, 1991; Volume 262, pp. 265-279. [CrossRef]

46. Dolan, J.; Mann, P.; De Zoeten, R.; Heubeck, C.; Shiroma, J.; Monechi, S. Sedimentologic, stratigraphy, and tectonic synthesis of Eocene-Miocene sedimentary basins, Hispaniola and Puerto Rico. In Geologic and Tectonic Development of the North America-Caribbean Plate Boundary in Hispaniola; Mann, P., Draper, G., Lewis, J.F., Eds.; Geological Society of America Special Paper: Boulder, CO, USA, 1991; Volume 262, pp. 217-240.

47. Merino, J.I.R.; Valera, F.P.; de Los Santos, M.A.; Braga, J.C.; Granados, L.; Zarza, A.A.; Fernandez, M.J.; Viruete, J.E.; Hernaiz, P.P.; Solé, J.E.; et al. Geological Map of Dominican Republic at 1:50,000 scale San Francisco Above (sheet 6074-I). In Geotematic Cartography Program of the Dominican Republic, Project 1B; General Directorate of Mining: Santo Domingo, Dominican Republic, 2010.

48. Eberle, W.; Hirdes, W.; Muff, R.; Pelaez, M. The geology of the Cordillera Septentrional (Dominican Republic). In Proceedings of the Transactions of the 9th Caribbean Geological Conference, Santo Domingo, Dominican Republic, 15-26 August 1980. 
49. Redmond, B. The Tertiary of the Central Cordillera Septentrional. In Proceedings of the Transactions of the 9th Caribbean Geological Conference, Santo Domingo, Dominican Republic, 15-26 August 1982.

50. Widera, M. Depoisitional environments of overbank sedimentation in the lignite-bearing Gray Clays Member: New evidence from Middle Miocene deposits of Central Poland. Sedim. Geol. 2016, 335, 150-165. [CrossRef]

51. Wagner, M. Petrologic studium of terrestrial organic matter in Carpathians flysch sediments, southern Poland. Int. J. Coal Geol. 1996, 29, 259-272. [CrossRef]

52. Kwiecińska, B.; Wagner, M. Pseudowitrynit i pseudohuminit-Mało poznane składniki kopalnego wegla/Pseudovitrinite and pseudohuminite-Not well known components of hard and brown coals. Zesz. Nauk. Politech. Ślaskiej 2001, 249, 75-81. (In Polish, English summary)

53. Kwiecińska, B.; Wagner, M. Atlas Petrograficzny Węgla Brunatnego: Litotypy i Maceraty/A Petrographic Atlas of Brown Coals (Lignites) from the Polish Deposits, 1st ed.; Wydawnictwo JAK Andrzej Choczewski; AGH University of Science and Technology: Kraków, Poland, 2001; ISBN 10: 83-914795-4-4. (In Polish, English summary)

54. Mernagh, T.P.; Trudu, A.G. A laser Raman microprobe study of some geologically important sulphide minerals. Chem. Geol. 1993, 103, 113-127. [CrossRef]

55. Wart, H.E.; Lewis, A.; Scherga, H.A.; Saeva, F.D. Disulfide bond dihedral angles for Raman Spectroscopy. Proc. Natl. Acad. Sci. USA 1973, 70, 2619-2623. [CrossRef] [PubMed]

56. Brody, R.H.; Edwards, H.G.M.; Pollard, A.M. A study of amber and copal samples using FT-Raman spectroscopy. Spectrochim. Acta A 2001, 57, 1325-1338. [CrossRef]

57. Downs, R.T. The RRUFF Project: An integrated study of the chemistry, crystallography, Raman and infrared spectroscopy of minerals. In Proceedings of the Program and Abstracts of the 19th General Meeting of the International Mineralogical Association, Kobe, Japan, 23-28 July 2006; Commision on Ore Mineralogy; Report of the Sulfofosalt Subcommittee; pp. 3-13.

58. Montoro, O.R.; Taravillo, M.; San Andrés, M.; De La Roja, J.M.; Barrero, A.F.; Arteaga, P.; Baonza, V.G. Raman spectroscopic study of the formation of fossil resin analogues. J. Raman Spectrosc. 2014, 45, 1230-1235. [CrossRef]

59. Barone, G.; Capitani, D.; Mazzoleni, P.; Proietti, N.; Raneri, S.; Longobardo, U.; Di Tullio, V. ${ }^{13}$ C Solid State Nuclear Magnetic Resonance and $\mu$-Raman Spectroscopic Characterization of Sicilian Amber. J. Appl. Spectrosc. 2016, 70, 1346-1355. [CrossRef]

60. Nims, C.; Cron, B.; Wetherington, M.; Macalady, J.; Cosmidis, J. Low frequency Raman Spectroscopy for micron-scale and in vivo characterisation of elemental sulphur in microbial samples. Sci. Rep. 2019, 9, 7971-7982. [CrossRef]

61. Wesełucha-Birczyńska, A.; Toboła, T.; Natkaniec-Nowak, L. Raman microscopy of inclusions in blue halites. Vib. Spectrosc. 2008, 48, 302-307. [CrossRef]

62. Wesełucha-Birczyńska, A.; Natkaniec-Nowak, L. A Raman microspectroscopic study of organic inclusions in "watermelon" tourmaline from the Paprok mine (Nuristan, Afghanistan). Vib. Spectrosc. 2011, 57, 248-253. [CrossRef]

63. Wilkins, R.W.T.; Boudou, R.; Sherwood, N.; Xiao, X. Thermal Maturity Evaluation from Inertinites by Raman Spectroscopy: The 'RaMM' Technique. Int. J. Coal Geol. 2014, 128-129, 143-152. [CrossRef]

64. Wilkins, R.W.T.; Wang, M.; Gan, H.; Li, Z. A RaMM Study of Thermal Maturity of Dispersed Organic Matter in Marine Source Rocks. Int. J. Coal Geol. 2015, 150-151, 252-264. [CrossRef]

65. Wesełucha-Birczyńska, A.; Toboła, T. Hydrocarbon alteration in the bituminous salt of the Kłodawa Salt Dome (Central Poland). Mar. Pet. Geol. 2016, 75, 325-340. [CrossRef]

66. Hardcastle, F.D. Raman Spectroscopy of Titania $\left(\mathrm{TiO}_{2}\right)$ Nanotubular Water-Splitting Catalysts. J. Ark. Acad. Sci. (JAAS) 2011, 65, 43-48.

67. Naglik, B.; Mroczkowska-Szerszeń, M.; Dumańska-Słowik, M.; Natkaniec-Nowak, L.; Drzewicz, P.; Stach, P.; Żukowska, G. Fossil Resins-Constraints from Portable and Laboratory Near-infrared Raman Spectrometers. Minerals 2020, 10, 104. [CrossRef]

68. Seyfullah, L.J.; Beimforde, C.; Dal Corso, J.; Perrichot, V.; Rikkinen, J.; Schmidt, A.R. Production and preservation of resins-Past and present. Biol. Rev. 2018, 93, 1684-1714. [CrossRef]

69. UN; ECE. Committee on Sustainable Energy. In International Codification System for Low-Rank Coal Utilization; United Nations: New York, NY, USA; Geneva, Switzerland, 2002.

70. ISO 11760-2007. Coal Classification/Klasyfikacja Wegla; National Standards Authority in Poland (Polski Komitet Normalizacyjny): Warsaw, Poland, 2007; p. 16, ISBN 978-83-251-2358-1. 
71. Kosmowska-Ceranowicz, B.; Sachanbiński, M.; Łydżba-Kopczyńska, B. Analytical characterization of "Indonesian amber" deposits: Evidence of formation from volcanic activity. Baltica 2017, 30, 55-60. [CrossRef]

72. Yeates, D.; Grimaldi, D. A new Metatrichia window fly (Diptera: Scenopinidae) in Dominican amber, with a review of the systematics and biogeography of the genus. Am. Mus. Novit. 1993, 3078, 1-8.

73. Zuparko, R.L.; Poinar, G.O., Jr. Aivalykus dominicanus (Hymenoptera: Braconidae), a new species from Dominican amber. Proc. Entomol. Soc. Wash. 1997, 99, 744-747.

74. Zavortink, T.J.; Poinar, G.O., Jr. Anopheles (Nyssorhynchus) dominicanus sp. n. (Diptera: Culicidae) from Dominican amber. Ann. Entomol. Soc. Am. 2000, 93, 1230-1235. [CrossRef]

75. Sinninghe Damste, J.S.; Eglinton, T.I.; de Leeuw, J.W.; Schenck, P.A. Organic sulphur in macromolecular sedimentary organic matter. I. Structure and origin of sulphur-containing moieties in kerogen, asphaltenes and coal as revealed by flash pyrolysis. Geochim. Cosmochim. Acta 1989, 53, 873-889. [CrossRef]

76. Sinninghe Damste, J.S.; De Leeuw, J.W. Analysis, structure and geochemical significance of organically-bound sulphur in the geosphere: State of the art and future research. Org. Geochem. 1990, 16, 1077-1101. [CrossRef]

77. Stankiewicz, B.A.; Poinar, H.N.; Briggs, D.E.; Evershed, R.P.; Poinar, G.O., Jr. Chemical preservation of plants and insects in natural resins. Proc. R. Soc. Lond. Part B 1998, 265, 641-647. [CrossRef]

78. Wittenberg, G.; Danon, A. Disulfide bond formation in chloroplasts. Formation of disulfide bonds in signaling chloroplast proteins. Plant Sci. 2008, 175, 459-466. [CrossRef]

79. Callegaro, S.; Baker, D.R.; De Min, A.; Marzoli, A.; Geraki, K.; Bertrand, H.; Viti, C.; Nestola, F. Microanalyses link sulphur from large igneous provinces and Mesozoic mass extinctions. Geology 2014, 42, 895-898. [CrossRef]

80. Kucha, H. Precious metal alloys and organic matter in the Zechstein copper deposits, Poland. Tschermaks Mineral. Petrogr. Mitt. 1981, 28, 1-16. [CrossRef]

81. Brouwer, S.B.; Brouwer, P.A. Geologia de la region ambarifera oriental de la Republica Dominicana. In Proceedings of the Transactions of the 9th Caribbean Geological Conference, Santo Domingo, Dominican Republic, 15-26 August 1982.

82. Martín-González, A.; Wierzchos, J.; Gutiérrez, J.C.; Alonso, J.; Ascaso, C. Double fossilization in eukaryotic microorganisms from Lower Cretaceous amber. BMC Biol. 2009, 7, 9. [CrossRef]

(C) 2020 by the authors. Licensee MDPI, Basel, Switzerland. This article is an open access article distributed under the terms and conditions of the Creative Commons Attribution (CC BY) license (http://creativecommons.org/licenses/by/4.0/). 